\title{
The internal syntax of adverbial clauses *
}

Liliane Haegeman (liliane.haegeman@Gent.be)

Lingua, 120, 3, March 2010, 628-648.

\section{Aim and scope of the paper: restrictions on finite adverbial clauses}

The starting point of this paper is the observation that English temporal and conditional clauses resist argument fronting. A movement analysis of adverbial clauses (going back to Geis (1970, 1975), and adopted by, among others, Larson (1985, 1987, 1990), Demirdache and Uribe-Etxebarria (2004: 165-176), Bhatt and Pancheva (2006), Liptàk (2005), Tomaszewicz (to appear), Citko (2000)) allows us to analyse this restriction in terms of an intervention effect. The movement account allows us to predict (i) that not all English adverbial clauses are incompatible with argument fronting, (ii) that Romance adverbial clauses are compatible with clitic left dislocation, and (iii) that temporal adverbial clauses contain a trigger for French Stylistic Inversion.

\subsection{Adverbial clauses and argument fronting in English}

Temporal and conditional adverbial clauses resist root transformations/ main clause phenomena (MCP) such as argument fronting in English (Rutherford 1970, Hooper and Thompson 1973, Emonds 2004). ${ }^{1}$

(1) a *While this paper I was revising last week, I thought of another analysis.

b *When her regular column she began to write again, I thought she would be OK.

c $\quad *$ If these exams you don't pass, you won't get the degree.

Cross-linguistically adverbial clauses resist MCP. For instance, Hernanz (2007a,b) shows how Spanish adverbial clauses display restrictions on emphatic polarity markers sí and bien. Similarly, in Icelandic adverbial clauses, V2 is not possible, despite the fact that it is available in declarative complement clauses (Holmberg 2005b, note 4, see also Sigurdsson 1989, Rögnvaldsson \& Thrainsson 1990). Similar restrictions on V-movement in Northern Norwegian are observed in Bentzen et al.(2007, and Julien (2008). See Heycock (2006) for general discussion of MCP. 
In an early discussion of the distribution of MCP, Hooper and Thompson (1973) offer a semantic/pragmatic account: MCP such as argument fronting depend on assertion. They make the point that the restriction cannot be accounted for syntactically.

As a positive environment we can say that [root] transformations operate only on Ss that are asserted. ... some transformations are sensitive to more than just syntactic configurations. It does not seem possible to define the domain of an RT in terms of syntactic structures in any general way. However, ..., even if it were possible to define in syntactic terms the conditions under which RTs can apply, ... the question of why these transformations can apply in certain syntactic environments and not others would still be unanswered (Hooper \& Thompson 1973: 495, my italics)

The goal of the present paper is to take up this challenge and to elaborate a syntactic account for the restriction in $(1)^{2}$

\subsection{Outline}

The paper is organised as follows: Section 2 presents my earlier account of the data discussed above. This account relied heavily on the crucial role of Force in the left periphery. The section also points out the problems with this account. Starting from the observed adjunct/argument asymmetry in the left periphery of adverbial clauses, section 3 elaborates an alternative account according to which temporal and conditional clauses are derived by operator movement. The incompatibility with argument fronting in English is then analysed as an intervention effect. In section 4 I examine some predictions made by this account. Section 5 is a conclusion to the paper.

\section{A first account}

\subsection{Adverbial clauses and high adverbs}

In the literature $\mathrm{s}$ it has often been observed that expressions of epistemic modality are not compatible with temporal or conditional adverbial clauses. (2b) and (2c) are from Declerck and Depraetere (1995: 278), see also Palmer (1990: 121, 182), Verstraete (2002). ${ }^{3}$

(2) a *??John works best while his children are probably/may be asleep.

b *John will do it when/if he may/must have time. 
c *We met John before he must have tampered with the tapes. (Heinämäkki 1978: 22$)^{4}$

In terms of the Cinque $(1999,2004)$ hierarchy of adverbials reproduced in (3), the top four adverb classes are incompatible with temporal and conditional adverbial clauses:

$$
\begin{aligned}
& \text { MoodP }_{\text {speech act }}>\text { MoodP }_{\text {evaluative }}>\text { MoodP }_{\text {evidential }}>\text { ModP }_{\text {epistemic }}>\mathrm{TP}(\text { Past })>\mathrm{TP} \text { (Future) } \\
& >\operatorname{MoodP}_{\text {irrealis }}>\operatorname{ModP}_{\text {alethic }}>\operatorname{AspP}_{\text {habitual }}>\mathrm{AspP}_{\text {repetitive }}>\mathrm{AspP}_{\text {frequentative }}>\operatorname{ModP}_{\text {volitional }}> \\
& \mathrm{AspP}_{\text {celerative }}>\mathrm{TP}(\text { Anterior })>\mathrm{AspP}_{\text {terminative }}>\mathrm{AspP}_{\text {continuative }}>\mathrm{AspP}_{\text {retrospective }}> \\
& \mathrm{AspP}_{\text {proximative }}>\mathrm{AspP}_{\text {durative }}>\mathrm{AspP}_{\text {generic }} /_{\text {progressive }}>\mathrm{AspP}_{\text {prospective }}>\mathrm{ModP}_{\text {obligation }}> \\
& \mathrm{ModP}_{\text {permission/ability }}>\mathrm{AspP}_{\text {completive }}>\mathrm{VoiceP}>\mathrm{AspP}_{\text {celerative }}>\mathrm{AspP}_{\text {repetitive }}>\mathrm{AspP}_{\text {frequentative }} \\
& \text { (Cinque 2004: 133, his (3)) }
\end{aligned}
$$

Speech act adverbials are incompatible with temporal and conditional adverbial clauses (cf. Rutherford 1970): ${ }^{5}$

(4) ??*When/if frankly he is unable to cope, we '1l have to replace him.

Evaluative adverbs are also not easily compatible with temporal and conditional adverbial clauses:

(5) *If they luckily arrived on time, we will be saved. (Ernst 2007: 1027, Nilsen 2004). ${ }^{6}$

Evidential modality is also excluded in temporal or conditional clauses. I illustrate this point on the basis of the syntax of Italian sembrare ('seem'), which can be used either as a lexical verb, in which case it is compatible with a dative argument and disallows clitic climbing, or as a functional verb, in which case it is not compatible with a dative argument and allows clitic climbing (Cinque 1999: 94, 2002, 2004, Haegeman 2006b). As shown in (6a,b) lexical sembrare may turn up in conditional clauses, functional sembrare -which allows clitic climbing- may not: ${ }^{7,8}$

(6) a Se sembrano trovarlo troppo difficile, faremo il secondo capitolo. if seem-3PL find-it too difficult, do-FUT-1PL the second chapter 'If they seem to find it too difficult, we'll do the second chapter.' 
b *Se lo sembrano trovare troppo difficile, faremo il secondo capitolo. if it seem-3PL find too difficult, do-FUT-1PL the second chapter

The modality markers which are incompatible with adverbial clauses have in common the fact that they are anchored to the speaker (Tenny 2000: 29). Thus, temporal and conditional adverbial clauses are incompatible with speaker related adverbs.

\subsection{A link between topicalisation and high adverbs?}

That both argument fronting and high modality markers are incompatible with adverbial clauses is not English specific. Whitman (1989:5) points out the same correlation in Korean and in Japanese. Bayer (2001:14-15) links both topicalisation and modal adverbs to the availability of illocutionary force. Inspired by Bayer's proposal, I elaborated an account which made argument fronting and high adverbs and modal auxiliaries dependent on the presence of illocutionary force. The latter was formally represented in the syntax by a functional head Force in the left periphery. In the next section I first sketch this account and then discuss some drawbacks. For an elaboration of the proposal, see Haegeman (2006b,c).

\subsection{A previous 'cartographic' account (Haegeman 2003a etc)}

\subsubsection{The articulated structure of $C P$}

Rizzi (1997) adopts the view that the highest head of the CP system is Force, which hosts the conjunction. In my first account of the restrictions on adverbial clauses, I adopted a variant of this in which two heads were distinguished: 'Sub' and 'Force' (cf. Bhatt and Yoon 1992). ${ }^{9}$ Subordinating conjunctions are merged in 'Sub'; 'Sub' subordinates the clause, 'makes it available for (categorial) selection independently of its force' (cf. Rizzi 1997: note 6). 'Force' was a separate head hosting the feature for 'illocutionary force' and which types the clause in terms of assertion, question, imperative etc. In line with Tenny's (2000) observations on higher adverbs and also inspired by Bayer (2001), I postulated that argument fronting and speaker-related adverbs were dependent on the availability of the functional head Force. I proposed that full-fledged clauses had the structure in (7). ${ }^{10}$

(Sub) Top* Focus Force Fin IP 


\subsubsection{Truncation (=structural reduction) in the left periphery}

To account for the non-availability of argument fronting and high adverbs in adverbial clauses, I proposed that adverbial clauses had a truncated functional structure (8): Force did not project and because of this Top and Foc did not project either. (i) In the absence of TopP, argument fronting would not be possible. (ii) In the absence of Force, speaker-related modal expressions, which I assumed to be dependent on Force, would also not be licensed.

Adverbial clauses ('reduced'):

Sub Fin IP

I refer the reader to my papers (Haegeman 2003a, 2006b, 2006c) for more discussion. Various authors have explored the consequences of my account. Munaro (2005) adopts the analysis to account for fronting of Italian conditional clauses, Bocci (2007) adopts the proposal in relation to focus in the Italian left periphery, Cardinaletti (to appear) adopts my proposal to account for Italian resumptive preposing, Hernanz (2007a,b) uses the truncation account to account for the expression of emphatic polarity (si, bien) in Spanish. Bentzen et al (2007) and Julien (2008) use the truncation analysis to characterise the constraints on embedded verb second in Scandinavian. Abels and Muriungi (2008: 693-4) adopt the analysis to account for some restrictions on focus marking in Kîitharaka. See also Papadopoulou et al (this volume).

\subsubsection{Problems for the analysis}

\subsubsection{Circumstantial adjuncts are available in the left periphery of adverbial clauses}

A first problem that arose was that, while arguments cannot be fronted in English adverbial clauses, such clauses may contain initial adverbial adjuncts. ${ }^{11,12}$

(9) If on Monday we haven't found him, we'll call the RSPCA.

Given that Rizzi (1997) analyzes initial adjuncts such as on Monday in (9) as being adjoined to TopP, and assuming that temporal adverbial clauses lack TopP, (8) incorrectly rules out (9). I proposed to remedy this by postulating a specialised position for adjuncts, ModP (Rizzi (2004), Haegeman (2003b)), as in (10):

(10) a Root clauses:

Top Focus Force Mod Fin IP 
b Adverbial clauses:

Sub

Mod Fin

IP

Being dominated by ForceP, ModP was not affected by the truncation of ForceP. Hence, although truncated, temporal or conditional adverbial clauses remained compatible with fronted adjuncts (in SpecModP), while disallowing argument fronting (in SpecTopP).

\subsubsection{Romance languages allow argument fronting in the form of CLLD in} $\underline{\text { adverbial clauses }}$

A second problem for the account was that Clitic Left Dislocation (CLLD) is allowed in Romance temporal and conditional clauses (cf. also Cinque (1990: 58), Haegeman (2006b)), as shown in (11) (see Haegeman (2006a) for more examples):

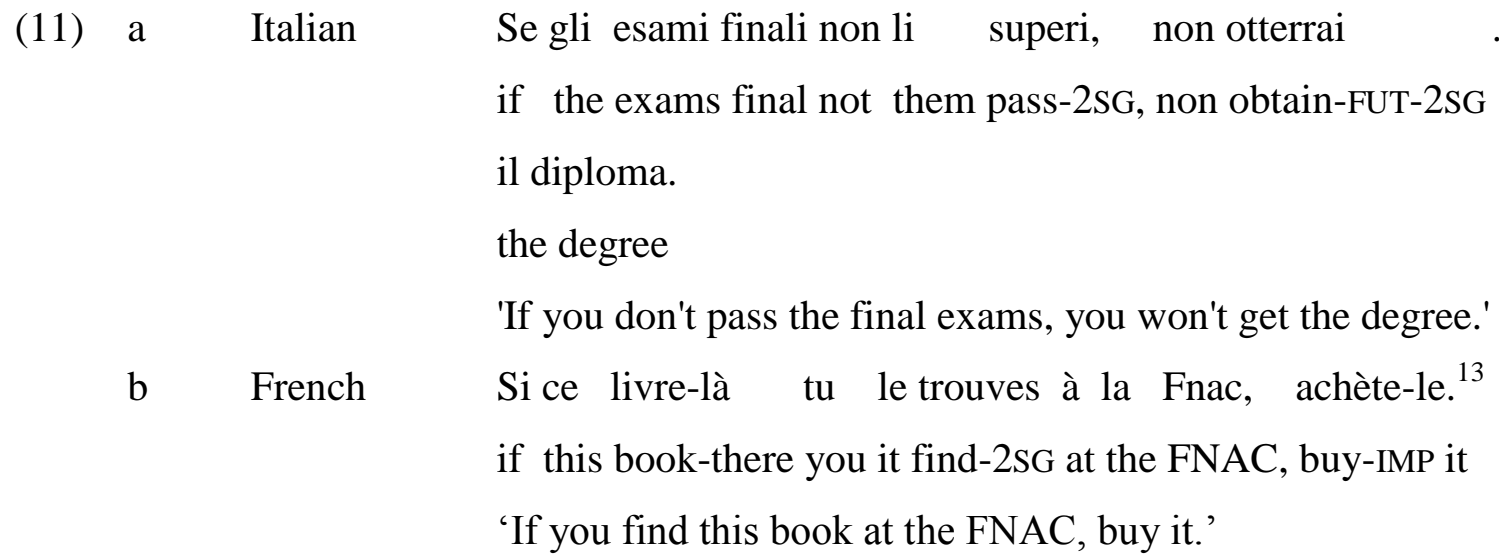

In order to allow CLLD in adverbial clauses, while excluding English on argument fronting, I proposed (Haegeman 2006a) that English fronted arguments occupy a higher position in the left periphery than their Romance CLLD counterparts. More specifically, CLLD arguments can occupy the specifier of a lower TopP, which is dominated by ForceP. ${ }^{14}$

(10) c Adverbial clauses: $\quad$ Sub $\quad$ Top Mod Fin IP

The lower variant of topicalisation, represented by CLLD, is not dependent on Force and is not available in English. This diversification of topics (cf. Frascarelli and Hinterholzl (2007) for distinct types of topics), with different licensers, leads to the conclusion that English topicalisation and CLLD must have quite a different semantics, the former being licensed through the presence of Force and the latter independent of Force. 


\subsubsection{The dependency of 'high' topics on Force}

A conceptual problem for the account is that it heavily relies on the availability of Force as a syntactic head. This in itself is not uncontroversial. For instance, Zanuttini \& Portner (2003) say explicitly: 'We argue there is no particular element in syntax responsible for introducing force.' (2003: 39, abstract). (Cf. Gärtner and Steinbach (2006)).

My earlier account relied on the intuition that topicalisation is related to illocutionary force, but this link was not made precise. For instance, the presence of illocutionary force as such cannot be a sufficient condition for argument fronting in English. Imperatives, which would presumably be said to be associated with illocutionary force, do not allow topicalisation in English (12a). Yes/no questions, and wh-questions, which would presumably also be argued to have illocutionary force, are incompatible with topicalisation $(12 \mathrm{~b}, \mathrm{c})$. The same goes for $w h$-exclamatives (12d):

(12) a Your essay, leave *(it) in my pigeon hole this afternoon.

b That book about shrimp, did you actually read *(it)? (cf. Sobin 2003: 194)

c That book about shrimp, when did you read *(it)?

d That book about shrimp, how much we all enjoyed *(it)!

What is needed to licence argument fronting, then, is not simply the presence of Force, but rather 'assertive' Force (Hooper and Thompson 1972, Palmer 1990) or 'declarative' force (Sobin 2003: 194). This makes the truncation approach harder to implement. Moreover, it is not clear that (assertive) force is definitely a prerequisite for argument fronting. Culicover and Levine (2001: 297) point out: 'gerundive clauses are rather more tolerant of topicalisation than infinitive clauses' and they give the example in (13). ${ }^{15}$

(13) That solution Robin having already explored t and rejected $t$, she decided to see if she could mate in six moves with just the rook and the two pawns. (2001: 297, note 14, their (ii))

It is not obvious that the gerundive clause in (13) corresponds to an assertive/declarative speech act. 
A further problem concerns the dependency of high adverbs on illocutionary force. In English small clause complements of with, and in the Italian counterparts, speaker-related evaluative, evidential and epistemic modals are available:

(14) a With John unfortunately/apparently/ probably unable to cope with the situation, we decided to turn to Mary.

b Con Gianni francamente inadatto a questo compito,... with Gianni frankly not suitable for this task

'As Gianni is frankly not up to this task...'

And indeed, on the basis of (14b), Cinque (1999: 223, note 5) says 'the fact that "small clauses" allow for the full range of AdvPs, including the highest ... suggests that structurally they may be full clauses with a lexical projection distinct from VP.'

Rather than postulating the absence of Force, one might make topicalization and the appearance of the speaker related adverbs dependent on the feature composition of Force. This is in essence what is proposed in Zagona (2007: 231) who says 'Epistemic modals are restricted to contexts in which the Force head is a speech event of reporting knowledge of belief, and in which Force has a feature that sets the deictic center'. Still, observe that it is not obvious that gerunds (13), and small clauses (14) are assertive. Indeed, defining the relevant force is difficult and leads to contradictions. To mention just one case, it is assumed that complements of factive predicates resist MCP in English (see also section 6) so one would have to assume that they are not assertive in the relevant sense. But Zubizaretta (2001: 201) says 'it is likely that factive predicates, which presuppose the truth of their propositional complement, contain an Ass(ertion) operator in its [sic, lh] CP.' For the definition of the relevant sentence type see also Meinunger (2005) and Heycock (2006), who concludes 'It is a general problem for work in this area that definitions given are vague and independent evidence for the validity of the concepts used often weak' (Heycock 2006: 190).

The problems raised by the account outlined above have led me to explore a different avenue. 


\section{Argument/adjunct asymmetries and a movement analysis}

\subsection{Argument/adjunct asymmetries}

One ingredient in the analysis is the observation that what gerundive clauses have in common with declaratives is that there is no overt formative marking force. Argument fronting in English seems to impose a negative requirement: Force must not be marked overtly. 'Declarative' force is the default force when there is no formative to specify force/clause type. (cf. Roberts and Roussou (2002: 141)). A second ingredient is the argument/adjunct asymmetry observed in adverbial clauses of the type we are interested in: while argument fronting is not possible in English adverbial clauses (cf. (1)), initial adjuncts are possible (but see McCloskey 2006) as shown in (9), repeated here as (15).

(15) If on Monday we haven't found him, we'll call the RSPCA.

Such argument/adjunct asymmetries are found elsewhere and in particular, such contrasts are found with respect to movement. As shown in (16a-c) wh-arguments cannot be extracted across fronted arguments: subject extraction leads to ungrammaticality (16a), the extraction of to whom is degraded (16b). Arguments can, however, be extracted across adjuncts (16c-d):

(16) a *This is a man who liberty $_{j} t_{i}$ would never grant $t_{j}$ to us. (Rizzi 1997: 307, his $(71 b))^{16}$

b ??The student to whom ${ }_{i}$, your book b $_{j}$ I will give $t_{i} t_{j}$ tomorrow.

c John Prescott is the person who in future $t$ will be in charge of major negotiations with the firefighters.

d The student to whom, tomorrow, I will give your book t.

Another environment in which an argument/ adjunct asymmetry arises is illustrated in (17). Subject auxiliary inversion is triggered by a fronted $w$ h-constituent. However, as we see in the attested (17a), an adjunct, the PP at last, can intervene between the fronted wh-constituent to whom and the inverted auxiliary will. In (17b), though, the argument a treaty like this between the wh-phrase to whom and the auxiliary would gives rise to ungrammaticality. For discussion see Haegeman (2000). 
(17) a So to turn this around and fulfil New Labour's historic mission, to whom ${ }_{\mathrm{i}}$ at last will the government turn $\mathrm{t}_{\mathrm{i}}$ ? (Guardian, Education 19.07.2005 page $6 \mathrm{col}$ 5)

b $\quad *$ To whom ${ }_{j}$ a treaty like this $\underline{i}_{i}$ would the government propose $t_{i} t_{j}$ ?

\subsection{The movement analysis of adverbial clauses}

Pursuing the observation that arguments do and adjuncts do not interfere with movement, I have elaborated an account according to which adverbial clauses are derived by movement of an operator to their left periphery. (18a) is a schematic representation. In such contexts argument fronting will give rise to an intervention effect (18b).

(18) a John left [CP when [IP Sheila left the office when.]]

b *John left [CP when the office [IP Sheila left the office when ]]

In (18) 'CP' is a clause typing projection; it corresponds to Rizzi's original 'Force' and may be specified as being declarative, (free) relative, interrogative etc.

Because fronted adjuncts in general do not give rise to intervention effects, as shown above (Haegeman 2003b), adjunct fronting will not interfere in the derivation of adverbial clauses, hence adjuncts are possible in the left periphery of an adverbial clauses. In the next sections, I briefly go over the arguments that have been advanced in support of the movement analysis of adverbial clauses. In section 3.2.1. I deal with temporal adverbial clauses, and in 3.2.2. I deal with conditional clauses. See also Haegeman (2007a).

\subsubsection{Temporal adverbial clauses}

\subsubsection{The proposal: (null) operator movement in adverbial clauses}

The hypothesis that adverbial clauses are derived by movement is due to Geis $(1970,1975)$ and is based on the observation that (19) is ambiguous between a high construal and a low construal of the temporal operator:

(19) John left when Sheila said he should leave. ${ }^{17}$

(i) high construal: John left at the time of Sheila's statement about his departure. 
(ii) low construal: John left at the time of departure requested by Sheila.

Adopting the movement analysis Larson $(1987,1990)$ proposes the following representations for high (19a) and low (19b) construal respectively:

(20) a John left [CP when ${ }_{i}$ [IP Sheila said [CP[IP he should leave ]] $\left.t_{i}\right]$ ]

b John left [CP when $_{\mathrm{i}}$ [IP Sheila said [CP [IP he would leave $\mathrm{t}_{\mathrm{i}}$ ]]] (Larson 1987)

There have been a number of implementations of the idea in, among others, Dubinsky and Williams (1995), Demirdache and Uribe-Etxebarria (2004: 165-176). The precise implementation is not relevant here. What the proposals have in common is that temporal adverbial clauses are derived by the movement of a temporal operator from within the IP domain to the $\mathrm{CP}$ area.

\subsubsection{Evidence for movement of temporal operators: island effects}

As shown by Larson (1990: 170), going back to Geis (1970, 1975), (21) provides support for the movement analysis. While the temporal operator when can be extracted from the complement clause of claimed in (21a), giving rise to low construal. Extraction of the same operator from the complement of the $\mathrm{N}$ claim in (22), an island for extraction, will give rise to a violation of the CNCP and hence ungrammaticality. (cf. Demirdache and UribeEtxebarria (2004: 165-176), Penner and Bader (1995)).

(21) I saw Mary in New York when [IP she claimed [CP that [IP she would leave.]]]

(i) high construal: at the time that she made that claim

(ii) low construal at the time of her presumed departure

(22) I saw Mary in New York

when [IP she made [DP the claim [CP that [IP she would leave.]]]]

(i) high construal: at the time that she made that claim

(ii) low construal: $\quad *$ at the time of her presumed departure

3.2.1.3. Some evidence for movement analysis

In Haegeman (2007a) I discuss some suggestive cross-linguistic and diachronic evidence for the derivation of temporal adverbial clauses in terms of operator movement. In many 
languages subordinating conjunctions are formally identical to sentence-initial interrogative or relative constituents; for which a movement analysis would be uncontroversial. This is the case for English, as shown in (23a-c) and in a number of other languages, some of which are listed in (23d):
(23) a When did he arrive?
b I wonder when he arrived.
c When he arrived, the place was in darkness.
d French: quand, Italian: quando, Catalan quan, Dutch: wanneer

In other cases, an IP-internal temporal adverb has developed into a conjunction. For instance, standard Dutch has two lexical items toen ('then'): one is a temporal adverb and may be found clause internally (24a) and the same item is also used as a conjunction (24b). It is tempting to analyse these data as illustrating a lexical split in the sense of Roberts and Roussou (2003: 42).

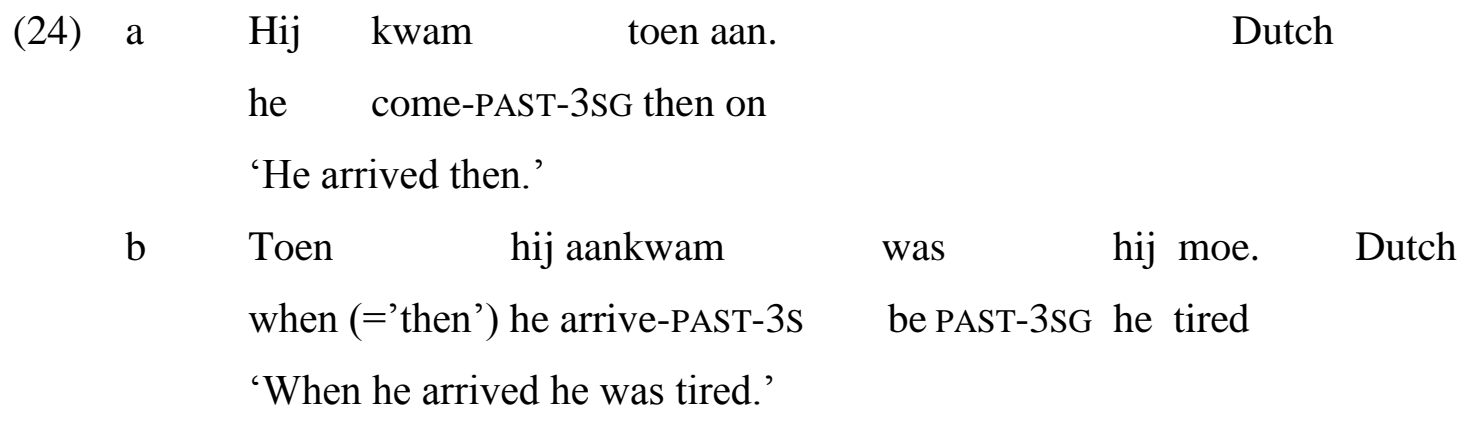

Similar analyses have been proposed for the derivation of adverbial clauses in other languages. Zribi-Hertz and Diagne (2003) show how Wolof adverbial clauses can be analysed as free relatives. Liptàk (2005) shows how Hungarian temporal clauses can be analysed as relative constructions. Citko (2000) discusses the derivation of temporal clauses in Polish. Against an LFG background, Stephens (2006) discusses the derivation of temporal clauses in Norwegian, arguing that some (though not all) are relative clauses. Papadopoulou et al (this volume: $\mathrm{xxx}$ ) point out that Greek kathos ('when, as soon as') and eno ('when, as soon as') diachronically consist of a preposition and a relative proform. ${ }^{18}$

\subsubsection{Conditional clauses}


Based on Geis (1970, 1975) and Larson (1985, 1987, 1990), Bhatt and Pancheva (2002, 2006) propose that conditional if-clauses be analysed as free relatives of possible worlds, derived by the leftward movement of a world operator. The reader is referred to Bhatt and Pancheva 's own paper for a discussion of some potential problems (2006: 656ff). In Haegeman (2008, to appear) I propose that the relevant world operator is that associated with FinP. Accordingly, an argument fronted to the left periphery will lead to an intervention effect:

(25) [CP OP if [TopP this book [FinP ӨP [IP you ... [vP find this book ]]]]]

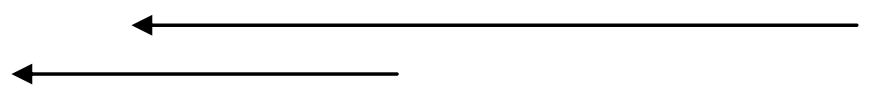

The case for conditional clauses being underlyingly free relatives is admittedly harder to make. ${ }^{19}$ One problem for the movement analysis of conditional clauses is the absence of the low construal reading (cf. (19) for low construal with temporal conjunctions) (cf. Bhatt and Pancheva 2006: 656ff): (26a) with temporal when has two readings, but (26b) with conditional if only has one reading: if is construed with the higher clause:

(26) a I will leave when you say you will do.

(i) high construal: I will leave at time of your announcement of your departure.

(ii) low construal: I will leave at the time of your departure.

b I will leave if you say you will do.

(i) high construal: I will leave on condition that you announce your departure.

(ii) *low construal: I will leave on condition that you leave.

Bhat and Pancheva (2006: 657) admit this problem but they point out that the same restriction is found in German, in which the conditional conjunction is wenn, i.e. equivalent to the whoperator. This conjunction may be interpreted either with a temporal reading or a conditional one. In its temporal reading wenn marginally allows low construal, but conditional wenn is only compatible with high construal:

(27) a Ich renne los wenn du mir sagst dass du losrennst.

I run-1SG- ahead when you me say-2SG that you ahead run-2SG

(high. OK; low: ?) 
b Ich renne nur los wenn du mir sagst dass du losrennst.

I run-1SG only ahead if you me say-2SG that you ahead run-2sG

(high : OK, low: *) (examples Bhatt and Pancheva 2002: 14)

There is some further support for the relative analysis of conditionals. Typically conditional conjunctions can be paraphrased by periphrastic expressions such as 'in case that', 'in the event that' and the French equivalent of these expressions clearly has the structure of a relative. In (28a), où ('where') is formally identical to the relative WH-operator où ('where') in (28b). Similarly, English to the extent that translates as dans la mesure où, again with the (obligatory) wh-operator où (28c). ${ }^{20}$

(28) a Au cas où tu le verrais, téléphone-moi.

in-the case where you him see-COND-2SG, call me

'If you should see him, call me.'

b La maison où il habite...

the house where he live-3SG

'the house where he lives...'

c Dans la mesure où vous êtes d'accord avec ces propositions

in the measure where you be-2PL of agreement with these proposals

'To the extent that you agree with these proposals...'

For a discussion of Polish conditional clauses in terms of a movement derivation see Tomaszewicz (to appear). In line with the present paper, the author shows that adopting the movement allows one to account for the ban on certain types of argument fronting in Polish conditionals. For reasons of space I will not go into the data here and I refer to her work for more discussion.

\subsection{CLLD in adverbial clauses}

It follows from the intervention account above that if there is a type of argument fronting which is independently known not to give rise to the same intervention effects as English argument fronting, then this type of argument fronting should be available in temporal or conditional clauses. Romance clitic left dislocation (CLLD) is a case in point: it does not give 
rise to the same intervention effects as argument fronting in English and it is allowed in temporal and conditional adverbial clauses.

Romance CLLD differs from English style argument fronting in that the intervention effects are notably reduced (cf. for analyses: Cinque 1990, Cecchetto 2000, De Cat 2004). ${ }^{21}$ For instance, multiple argument fronting leads to a degradation in English (29a-b) while multiple CLLD is possible (29c-d):

(29) a *This book , to Robin $_{j}$, I gave $t_{i} t_{j}$. (Culicover 1992).

b $\quad *$ Bill $_{\mathrm{i}}$, that house ${ }_{\mathrm{j}}$, she took $\mathrm{t}_{\mathrm{i}}$ to $\mathrm{t}_{\mathrm{j}}$ for the weekend (Emonds 2004: 95 (27b))

c Il libro, a Gianni, glielo darò senz' altro. the book, to Gianni him-it give-FUT-1SG without other 'I will give this book definitely to Gianni.'

(Rizzi 1997: 290, his (21))

A fronted topic creates an island in English, both for wh-movement (30a) and for topicalisation (30b), but in Italian a CLLD argument does not create an island for whmovement (30c,d) and for CLLD (30e):

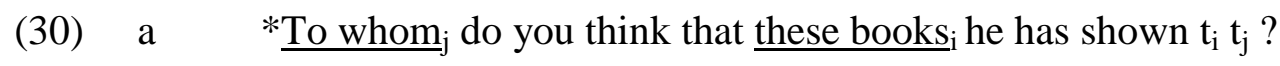

b *These books ${ }_{j} I$ think that his brother ${ }_{i}$ he has shown $t_{i} t_{j}$ ?

c ? Non so a chi pensi che, tuo fratello, lo potremmo affidare . (Rizzi 2004: his (64a))

'I don't know to whom you think that, your brother, we could entrust'

d ? Non so come pensi che, tuo fratello, lo potremmo convincere. (Rizzi 2004: his 64b)

'I don't know how you think that, your brother, we could convince him'

e Loro, il libro, credo che a Carlo sia sicuro che non glielo daranno them, the book, I think that to Carlo it is certain that non them it give-FUT-3PL mai.

ever. (Cinque 1990: 63, his (10))

In contrast to English inversion contexts, in which an argument may not intervene between the trigger for inversion and the auxiliary (cf. (17)), in French a fronted argument may intervene between a fronted wh-constituent and the inverted auxiliary: 
(31) Où ce livre (Jean) l'a -t-il

acheté? (Laenzlinger and Musolino 1995: 83)

where this book John it have-3SG-he bought

'Where did John buy this book?'

As discussed (11), CLLD and multiple CLLD (32) is allowed in adverbial clauses:

$\begin{array}{llll}\text { Se a Gianni } & \text { questo libro } & \text { non glielo mostro, sarà } & \text { molto deluso. } \\ \text { if to Gianni } & \text { this book } & \text { non him-it show-1SG, be FUT-3SG very disappointed }\end{array}$

If adverbial clauses are derived by movement, the availability of CLLD in adverbial clauses is expected because CLLD does not give rise to the typical intervention effects of other types of movement to the $\mathrm{CP}$ domain.

Observe that focalisation is not allowed in Italian adverbial clauses (judgements: L. Rizzi, p.c.):

(33) Italian a *Se IL MIO LIBRO riesci a leggere, supererai l'esame.
if MY BOOK manage-2sG to read, pass-FUT-2SG the exam b Se il mio libro riesci a leggerlo, supererai l'esame. if my book manage-2SG to read-it, pass FUT-2SG the exam 'If you manage to read my book, you'll pass the exam.'

Cardinaletti (to appear) discusses the contrast in (34): while CLLD is allowed in the conditional clause in (34a), preposing without a clitic is disallowed (34b).

(34) a ok Se la stessa proposta la fa anche l'altro candidato, if the same proposal it make-3SG also the other candidate, non otterrai quel posto.

non obtain-FUT-2SG that position

'If the other candidate makes the same proposal, you won't get the position.' (Cardinaletti to appear: 10: (22a)))

b * Se la stessa proposta fa anche l'altro candidato, if the same proposal make-3sG also the other candidate, non otterrai quel posto. 
non obtain-FUT-2SG that position (Cardinaletti to appear: 4: (19a)))

\section{Intervention effects}

\subsection{Extraction from weak islands}

In this section I briefly sketch the type of locality theory required to account for the intervention effects observed. The account remains fairly general, and different implementations are conceivable.

To account for the fact that the adjunct how cannot be extracted across whether (35a) while extraction of which problem in (35b) and relativization in (35c) are possible, concepts such as D-linking, referentiality, argument-status, thematic status, specificity, presuppositionality, topicality have been invoked in the literature (cf. Cinque 1990, Rizzi 2001, Starke 2001, Miyagawa 2004, Grohmann 2005, Endo 2007 etc.)

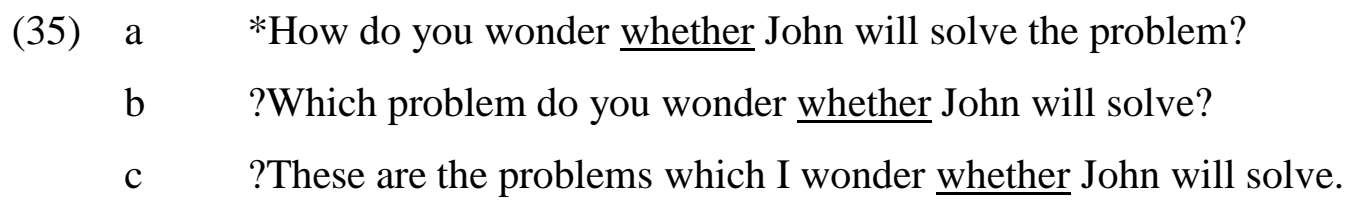

In other words, extraction out of a weak island (as that created by whether in (35)) is facilitated by an extra property. I represent the additional factor that is involved in overcoming the island by the symbol $\delta$. I leave it open whether this is a unitary factor or whether several of ingredients listed above may be involved (cf. Starke 2001).

I will adopt the proposal that a constituent with the feature $\alpha$ blocks extraction of a constituent with the same feature. However, following Starke (2001) the intervention effect induced by $\alpha$ can be overcome if the moved constituent has an additional feature (here $\delta$ ). I assume that wh-phrases, including whether, are associated with an operator feature, represented as Q. Schematically, the present/absent intervention effects in (35) could be summarized as in (36). In (36a), the feature Q on whether will intervene between a higher probe and a lower wh-constituent with the same feature Q. But in $(36 \mathrm{~b}, \mathrm{c})$ the blocking effect of the intermediate Q can be overcome if the probe/goal relation is constructed on the basis of $\mathrm{Q}$ and an additional feature (here $\delta$ ):

whether $\quad \mathrm{wh}_{\mathrm{int}}$ 
b

C

$\begin{array}{lll} & \text { whether } & \mathrm{wh}_{\text {int }}, \mathrm{D}-\text { linked } \\ \mathrm{Q}+\delta & \mathrm{Q} & \mathrm{Q}+\delta \\ \text { whether } & \mathrm{Rel} \\ \mathrm{Q}+\delta & \mathrm{Q} & \mathrm{Q}+\delta\end{array}$

In terms of a probe-goal relation one might adopt the following condition, from Lahne (2008):

(37) Maximizing matching principle

(Let $\pi$ be a Probe and P the feature set of $\pi$. Let $\gamma$ be a Goal in the search space of $\pi$ and $\mathrm{G}$ the feature set of $\gamma$.)

A feature set $\mathrm{Q} \subseteq \mathrm{P}$ with $|\mathrm{Q}| \geq 1$ must be satisfied with a feature set $\mathrm{H} \subseteq \mathrm{G}$ iff $\mathrm{H}$ is the most specific goal in the search space of $\pi$.

Specificity is determined by cardinality: A Match between $\mathrm{Q}$ and $\mathrm{H}$ is more specific than a Match between Q' and H' iff $|\mathrm{Q}|>\left|\mathrm{Q}^{\prime}\right|$ (Lahne (2008: Glow handout: p. 2, her (6))

For a similar recent proposal see also Landau (2008: 15 (his (54)):

(38) Featural A-over-A

Given $\left[\mathrm{X} \ldots\left[\mathrm{Y} \mathrm{Y}_{\alpha} \ldots \mathrm{Z}_{\beta}\right]_{\alpha}\right]$, where $\mathrm{X}, \mathrm{Y}, \mathrm{Z}$ are heads and $\alpha, \beta$ are feature sets: $\mathrm{Y}$ is an intervener for Agree $(X, Z)$ iff $\beta \subseteq \alpha$.

[i.e. the goal must be sufficiently different from the intervener to be accessible.]

\subsection{English Topics}

In English, fronted topics create islands for $w h$-extraction (39a,b,c), while they themselves can extract from weak islands (39d):

(39) a *Who did you say that to Sue Bill introduced (Boeckx \&Jeong 2004: (3))

b *How do you think that, this problem, we will solve ?

c *A student to whom, your book, I will recommend

d ?This problem, I wonder whether John will be able to solve 
Since they can escape from WI this suggests that fronted arguments are like D-linked and associated with the relevant feature that allows them to escape WI. Since they prevent $w h$ extraction they must share a feature with $w h$-constituents. Following (Boeckx \&Jeong 2004: 18) ${ }^{22}$ I assume that English fronted topics have the features $\delta+Q$, and that by virtue of this specification they will be interveners both for constituents which display the feature $\mathrm{Q}$ as well as for those with the feature specification $\delta+Q$.

If the operator which derives the adverbial clause also has the feature $\mathrm{Q}$, topicalisation in adverbial clauses gives rise to an intervention effect. (40) is a schematic representation:

$$
\begin{array}{ll}
{ }^{*} \text { when } & \text { this problem } \\
\mathrm{Q} & \delta+\mathrm{Q} \text { (topic) }
\end{array}
$$$$
\text { you are able to solve }
$$

Circumstantial adjuncts can occur in the left periphery of adverbial clauses because such adjuncts do not lead to the same type of intervention, as discussed in 2.3.3.1. They must be featurally distinct from the operator involved in the derivation of adverbial clauses.

\subsection{CLLD and lower topics}

The fronted argument in the CLLD construction must be featurally distinct from fronted arguments in English, since it does not lead to intervention effects (see (29) in section 3.3.). Quoting Rizzi: 'If topics form a separate class from other A' dependencies, we predict that we will not find locality interactions with other types of A' dependencies.' (Rizzi 2004: 245ff.) That such CLLD topics do not intervene in $w h$-fronting also allows one to predict that, differently from English (41a) a (CLLD) topic ( $a$ Gianni) may follow a focused constituent in Italian: (41b) is from Rizzi (2001, his (5)): ${ }^{23}$

(41) a $\quad *$ I think that to JOHN your book you should give

b Credo che ieri, QUESTO, a Gianni, i tuoi amici avrebbero think-1SG that yesterday THIS to Gianni the your friends have-cond-3PL dovuto dirgli. must-PARTICIPLE say-him 'I believe that yesterday, THIS, to Gianni, your friends should have said to him' 


\section{Two predictions of the account}

According to the movement account for temporal and conditional clauses, the incompatibility of such clauses with argument fronting in English is due to the typical intervention effect associated with fronted arguments in English. The account leads to a number of predictions two of which I will explore here. ${ }^{24}$

(i) If there are adverbial clauses that are arguably not derived by operator movement, then the intervention effect observed above will not arise and such adverbial clauses will be compatible with argument fronting. This is discussed in section 5.1. ${ }^{25}$

(ii) If a specific syntactic process is dependent on operator movement then it is predicted that it may be licensed in the temporal and conditional adverbial clauses derived by operator fronting and discussed above, and that it will not be automatically licensed in adverbial clauses which are not derived by operator movement discussed in section 5.1. Stylistic Inversion in French is such a process; the prediction that it is licensed in the adverbial clauses that are derived by operator movement is correct, as discussed in section 5.2.

\section{1. 'Peripheral' adverbial clauses (Haegeman 2003a)}

Bhatt and Pancheva (2006: 656) point out that not all adverbial clauses are derived by operator movement, they say: 'because and [rationale] since are sentential functions and not quantifiers, that is, they do not bind positions inside their clause'. We correctly predict that rationale clauses introduced by since or because, are compatible with argument fronting. $(42 a, b)$ are attested:

(42) a It is amazing how this view could have spread about someone who changed the image of causes like Aids and landmines, and in doing so showed a possible new role for the royals. It is particularly ironic since so much of what Diana did for her fellow humans she did with no concern for publicity whatsoever.

(Guardian, G2, 31.08.2004 page 9 col 2)

b I think we have more or less solved the problem for donkeys here, because those we haven't got, we know about. (Guardian, G2, 18.02.2003, page 3, col 2). 
The class of adverbial clauses which, by hypothesis, are not derived by operator movement is larger than that of rationale clauses. Whereas temporal while-clauses do not allow argument fronting, as seen above, adversative/concessive while-clauses allow argument fronting. Adverbial clauses introduced by (al)though also allow argument fronting:

(42) c His face not many admired, while his character still fewer felt they could praise. (Quirk et al 1985: 1378)

d We don't look to his paintings for common place truths, though truths they contain none the less. (Guardian, G2, 18.02.2003, page 8, col 1)

Rationale clauses, contrastive while clauses and although clauses belong to what I have labelled 'peripheral' adverbial clauses (Haegeman 2003a, 2006a). For reasons of space, I cannot go into a detailed discussion of such peripheral adverbial clauses here. Suffice it to say that there is ample evidence that their relation to the associated clause is not as tight as that observed for central adverbial clauses, ${ }^{26}$ see Haegeman (2003a), and also Papadopoulou et al (this volume), who use the diagnostics provided in Haegeman (2003a) for distinguishing two types of adverbial clauses in Modern Greek. I assume that peripheral adverbial clauses are not derived by operator movement to the left periphery. Hence they allow argument fronting.

The observed contrast carries over to conditional clauses. Conditional clauses introduced by the conjunction if either express a condition for the realisation of the event expressed in the main clause (43a), or they provide a proposition that serves as a background assumption which, combined with the assertion of the associated clause, yields additional inferences (43b) (see Haegeman (2003a)).

(43) a If your back-supporting muscles tire, you will be at increased risk of lowerback pain. (Independent on Sunday, Sports, 14.10.2001, page 29, col 3) (eventcondition)

b If we are so short of teachers ('Jobs crisis grows as new term looms', August 30), why don't we send our children to Germany to be educated? (Letters to the editor, Eddie Catlin, Norwich, Guardian, 31.08.2001, page 9, col 5) ('given that', background assumption)

A number of properties set those two types apart. For instance, in (43a) the central conditional clause is temporally subordinated to the main clause, with present tense tire being used to 
refer to a future eventuality; in (43b) present tense are in the peripheral clause refers to a present time ('we are now short of teachers'). Very often (as in (43b)), a peripheral conditional picks up a proposition that is salient in the discourse (cf. Palmer 1990: 182, Haegeman 2003a). Declerck and Reed (2001) characterise 'closed P-clauses', which correspond to my peripheral conditionals, as follows:

closed P-clauses are always echoic in one sense or another. They can echo straightforward statements about the actual world, or they can echo Q-propositions about a nonfactual world. ... They may also be echoes of an internal or mental proposition (thought) such as the interpretation of an experience, perception etc. (Declerck and Reed 2001:83)

Central conditionals are incompatible with argument fronting (1c); (echoic) peripheral conditionals are compatible with argument fronting:

(44) If some precautions they have indeed taken, many other possible measures they have continued to neglect.

Once again we would distinguish two instances of if clauses: one involving movement of an operator and one in which there is no such movement.

\subsection{French Stylistic Inversion}

French Stylistic Inversion (SI) SI is typically licensed by a moved WH-operator (cf. Kayne 1984, 1986, 2001, Rizzi 1990, Kayne and Pollock 2001, Lahousse 2003a,b) as in (45a) or by a preposed locative or temporal adverb or PP as in (46) ${ }^{27}$ from Lahousse (2003b: 136 (3)).

(45) a Quand est venue Marie? (Barbosa: 2001: 42, her (77))

when is come-PART-FSG Marie

'When did Mary arrive?'

b Je me demande quand est venue Marie. (Barbosa: 2001: 42, her (78))

I myself ask when is come-PART-FSG Marie

'I wander when Marie arrived.' 
(46)

a

$\underline{\text { Là }}$ se

nouaient

des relations nouvelles.

there themselves form-PAST-3PL relationships new

'There were formed new relationships.'

b Derrière la maison se trouve le jardin.

behind the house itself find -3SG the garden

'Behind the house can be found the garden.'

c et soudain surgirent six hommes noirs.

and suddenly emerge PAST-3PL six men black

'and suddenly there appeared six black men'

If French temporal adverbial clauses are derived by operator fronting and peripheral adverbial clauses (see 5.1.) do not implicate operator fronting, we expect a contrast in the way that SI is licensed. Temporal adverbial clauses should license SI, while adverbial clauses not derived by operator movement should require a specific trigger for SI. This prediction is correct.

Lahousse (2003a, 2003b) shows that in SI is licensed in temporal clauses:

Quand avait débuté le salon Sainte-Euverte

when have- PAST-3SG started the salon Sainte Euverte

'When the Salon Ste Euverte had opened...'

(Proust, quoted in Le Bidois 1952: 302) (Lahousse 2003a: 283 (5a))

Causal and concessive adverbial clauses, which I assume are not derived by operator movement (see section 5.1.), require the presence of an additional trigger for SI. Rationale adverbial clauses introduced by parce que ('because') and concessive bienque ('although') are a case in point. Lahousse finds that whenever such clauses display SI there is an additional trigger in the clause. In (48a) the adverbial là ('there') is the trigger, in (48b) it is the fronted PP dans leurs conversations ('in their conversations') (Lahousse: 2003b).

(48) a. Bien que dans leur conversation résonnât even though in their conversation sound-PAST-3SG une rumeur qui ne semblait pas nouvelle, a rumour that NEG seem PAST-3SG not novel

'Although in their conversations could be heard a rumour that was familiar,' (Lahousse 2003a: 282: (4a)) 
b

Un nom prédestiné, parce que là renaîtrait le phénix

a name predestine-PART because there re-arise-COND-3SG the phoenix (Japrisot, La dame dans l'auto avec des lunettes et un fusil, 1966)

'A predestined name because there would be reborn the phoenix.' (Lahousse 2003a: 319 (39a))

Based on an extensive written corpus, Lahousse (2003a,b) shows that while between $40-45$ per cent of temporal adverbial clauses display SI without there being an additional trigger, in all concessive or causal adverbial clauses with SI an additional trigger is available. ${ }^{28}$

\section{Conclusion and further questions}

I have proposed that the incompatibility of English adverbial clauses with argument fronting can be accounted for in purely syntactic terms if we adopt the hypothesis that the relevant adverbial clauses are derived by operator extraction. The ungrammaticality of (49) would be due to a locality violation.

(49) *If/when the text you have received, you should contact me.

The question arises if the intervention account can account for the incompatibility of other environments with argument fronting. I briefly discuss some such cases here.

Clausal complements of factive predicates resist argument fronting in English:

(46) (\%)*John regrets that this book Mary read. ${ }^{29}$ (Maki et al 1999: p. 3, their (2c))

It might be possible to extend the movement account to factive complements if one assumes with Melvold (1991) and Bianchi (2000:95) that such complements involve an operator in their $\mathrm{CP}$ domain. If this operator has moved from a lower position, then the ungrammaticality of (50) is due to an intervention effect. Support for a movement account is found in Aboh (2005), who discusses the derivation of complements of factive verbs in Gungbe. In Gungbe, factive complements formally resemble relatives involving either the movement of an argument or the movement of a verb to the left periphery. Aboh proposes that factive clauses are derived by (event-) operator fronting. Cf. Collins (1994). 
Argument fronting is also excluded in clauses that seem to be complements to N. See Kayne (2008) for a recent relativization account of N-complements, in a different context.

(51) * A warning that flights to Chicago travellers should avoid will soon be posted. (Emonds 2004: 77, his (2c)).

English present subjunctives are also incompatible with argument fronting (52). It has been proposed that subjunctive clauses contain an operator in Spec CP (Kempchinsky 1987). If this operator has been moved from a lower position, then the ungrammaticality of (40) is again due to an intervention effect. See also Tomaszewic (to appear) for a proposal for Polish subjunctives.

(52) *It's important that the book he study carefully (Hooper\&Thompson 1973: 485, (166))

Other domains that are incompatible with MCP are not so obviously amenable to a movement account. For instance, subject clauses also resist argument fronting. ${ }^{30} \mathrm{~A}$ complication here is that the extraposed variant of such 'subject clauses' does allow for argument fronting. ${ }^{31}$

(53) a *That this book, Mary read thoroughly is true. (Authier 1992: 332, his (17b))

b It is true that this book, he read thoroughly. (Authier 1992: 333, his (18b))

I hope to be able to clarify some of these issues in future work.

\section{References}

Abels, K. Muriungi,P., 2008. The focus marker in Kîitharaka: syntax and semantics. Lingua $118,687-731$.

Aboh, E. 2005., Deriving relative and factive constructions in Kwa. In: Brugè, L, Giusti, G., Munaro, N., Schweikert,W., Turano, G. (Eds.), Contributions to the Thirtieth Incontro di Grammatica Generativa. Libreria Editrice Cafoscarina, Venezia, pp. 265-285.

Adger, D., DeCat, C., Tsoulas, G. (Eds.), 2004. Peripheries. Kluwer : Dordrecht Alexopoulou, T., Doron, E., Heycock, C., 2004. Broad subjects and Clitic Left Dislocation. In: Adger et al (Eds.), pp. 329-298. 
Anagnostopoulou, E., van Riemsdijk, H., Zwarts, F. (Eds.), 1997. Materials on Left Dislocation. John Benjamins, Amsterdam.

Authier, J.-M., 1992. Iterated CPs and embedded topicalisation. Linguistic Inquiry 23, 329336.

Barbosa, P., 2001. On inversion in WH-questions in Romance. In: Hulk, A., Pollock, J.Y. (Eds.), Subject Inversion in Romance and the Theory of Universal Grammar. Oxford University Press, Oxford, pp. 20-59.

Bayer, J., 2001. Asymmetry in emphatic topicalization. In: Féry, C., Sternefeld, W. (Eds.), Audiatur Vox Sapientiae. Studia Grammatica 52, 15-47.

Benincà, P., Poletto, C., 2004. Topic, Focus and V2: Defining the CP sublayers. In: Adger, et al,. pp. 52-75.

Bentzen, K., Hrafnbjargarson, G.H., Hróarsdottir, T., Wiklund, A.-L., 2007a. The Troms $\varnothing$ guide to the Force behind V2. Working Papers in Scandinavian Syntax 79, 99-118.

Bhatt R., Yoon, J., 1992. On the composition of Comp and parameters of V-2. In: Bates, D. (Ed.), Proceedings of WCCFL. CSLI, Stanford, 10, pp. 41-53.

Bhatt, R., Pancheva, R., 2002. A cross -constructional analysis of if clauses. Paper presented at the Syntax Seminar: Interface in the CP domain, Zentrum fur Allgemeine Sprachwissenschaft, Berlin, March 9, 2002.

Bhatt, R., Pancheva, R.,. 2006. Conditionals. In: Everaert, M., van Riemsdijk, H. (Eds.), The Blackwell Companion to Syntax. Vol 1. Blackwell, Boston \& Oxford, pp. 638-687.

Bianchi, V. On time adverbials. Rivista di Lingusitica 12, 77-106.

Boeckx, C. and K. Grohmann.2004. Sub-move: Towards a unified account of scrambling and D-linking. In : D. Adger, C. de Cat and G. Tsoulas (eds) Peripheries. Dordrecht: Kluwer.

Boeckx, C., Yeong, J., 2004. The Fine Structure of Intervention in Syntax. In: Kwon, C., Lee, W. (Eds.), Issues in Current Linguistic Theory: A Festschrift for Hong Bae Lee. Kyungchin, Seoul, pp. 83-116. [Reprinted in: Boeckx, C., 2008. Aspects of the Theory of Agreement. Routledge, London, pp. 162-182]

Bocci, G., 2007. Criterial positions and left periphery in Italian. Evidence for the syntactic encoding of contrastive focus. Nanzan Linguistics, Special Issue. 3.

Boeckx, C. \& Y. Jeong. 2004. The fine structure of intervention in syntax.' In: Chungja Kwon \& Wonbin Lee (eds), Issues in Current Linguistic Theory: A Festschrift for Hong Bae Lee, Seoul: Kyungchin. Pp. 83-116.

Browning, M., 1996. CP recursion and that-t effects. Linguistic Inquiry 27, 237-256. 
Cardinaletti, A., to appear. On a (wh-) moved Topic in Italian, compared to Germanic. proceedings of the Comparative . Proceedings of the Germanic Syntax Workshop held in Stuttgart 2007.

Cecchetto, C., 2000. Doubling structures and reconstruction. Probus 12, 93-126.

Cinque, G., 1990. Types of A' dependencies. MIT Press, Cambridge MA.

Cinque, G., 1999. Adverbs and Functional Heads. Oxford University Press, Oxford and New York.

Cinque, G., 2002. A note on "restructuring" and quantifier climbing in French. Linguistic Inquiry 33, 617-636.

Cinque, G., 2004. "Restructuring" and functional structure. In Belletti, A. (Ed.), Structures and Beyond. The Cartography of Syntactic Structures (Vol 3). Oxford University Press, Oxford, pp. 132-191.

Citko, B., 2000. On the syntax and semantics of Polish adjunct clauses. Journal of Slavic Linguistics 8, 5-27.

Collins, C., 1994. The factive construction in Kwa. Ms. Cornell University.

Coniglio., M. 2007. German modal particles in root and embedded clauses. University of Venice Working Papers in Linguistics 17, 1-32.

Culicover, P., 1992. Topicalisation, inversion and complementisers in English. In: Delfitto, D. et al (Eds.), Going Romance and Beyond. OTS Working papers, Utrecht: University of Utrecht, pp. 1-44

Culicover, P. W., Levine, R. D., 2001. Stylistic inversion in English: a reconsideration. Natural Language and Linguistic Theory 19, 283-310.

Davies, W., Dubinsky, S., 1999. Sentential subjects as complex NPs: New reasons for an old account of subjacency. CLS 34, 83-94.

De Cat, C., 2004. Dislocation without movement ZAS papers in Linguistics 35, vol 1. Proceedings of the Dislocated Elements Workshop, November 2003, pp. 77-109.

Declerck, R., 1997. When-clauses and temporal structure. Routledge: London.

Declerck, R., Reed, S., 2001. Conditionals: a Comprehensive Empirical Analysis. Berlin: Mouton de Gruyter.

Declerck, R., Depraetere, I., 1995. The double system of Tense forms referring to future time in English. Journal of Semantics 12, 169-310.

Demirdache, H., Uribe-Etxebarria, M., 2004. The syntax of time adverbs. In Guéron, J., Lecarme, J. (Eds.), The Syntax of Time. MIT press, Cambridge MA, pp.143-180. 
Dubinsky, S., Williams, K., 1995. Recategorization of prepositions as complementizers: the case of temporal prepositions in English. Linguistic Inquiry 26, 125-137.

Emonds, J., 1970. Root and Structure-Preserving Transformations. Doctoral Dissertation. MIT.

Emonds, J., 1970. A Transformational Approach to English Syntax. Academic Press: New York.

Emonds, J., 2004. Unspecified categories as the key to root constructions. In: Adger et al (Eds.), pp. 75-121.

Endo, Y. 2007. Locality and information structure. John Benjamins. Amsterdam/ Philadelphia.

Ernst, T., 2007. On the role of semantics in a theory of adverb syntax. Lingua 117, 10081033.

Ernst, T., 2008. Speaker-oriented adverbs. Ms. Umass: Amherst.

Frascarelli, M., Hinterhölzl, R., 2007. Types of Topics in German and Italian. In: Winkler, S. and Schwabe, K. (Eds.), On Information Structure, Meaning and Form, John Benjamins, Amsterdam/ Philadelphia, pp. 87-116.

Gaertner, H.-M, Steinbach, M., 2006. A skeptical note on the syntax of speech acts and point of view. In: Brandt, P., Fuss, E. (Eds.), Form, Structure, Grammar. Akademie-Verlag, Berlin, pp. 213-222.

Geis, M., 1970. Adverbial Subordinate Clauses in English. Ph.D. Diss. MIT Cambridge:.

Geis, M., 1975. English time and place adverbials. Working Papers in Linguistics 18, Ohio State University, pp. 1-11.

Geis, M., 1985. The syntax of conditional sentences. In: Geis, M. (Ed.), Studies in Generalised Phrase Structure Grammar. Columbus, OH: Department of Linguistics, OSU, pp. 130-159.

Green, G. M., 1996. Distinguishing main and subordinate clause: the ROOT of the problem. Ms. University of Illinois.

Grohmann, K. (1998) Syntactic inquiries into discourse restrictions on multiple interrogatives. Groninger Arbeiten zur Germanistischen Linguistik 42: 1-60.

Haegeman, L., 2000. Negative preposing, the Neg criterion and the structure of CP. In: Horn, L., Kato, Y. (Eds.), Negation and Polarity. Oxford University Press, Oxford and New York, pp. 29-69.

Haegeman, L., 2003a. Conditional clauses: External and internal syntax. Mind and Language $18,317-339$. 
Haegeman, L., 2003b. Notes on long adverbial fronting in English and the left periphery. Linguistic Inquiry 34, 640-649.

Haegeman, L., 2005. Functional heads, lexical heads and hybrid categories. In: Broekhuis, H., Corver, N., Huybregts, R., Kleinhenz, U, Koster, J. (Eds.), Organizing Grammar. Linguistic Studies in Honor of Henk van Riemsdijk. Mouton De Gruyter, Berlin, pp. 152-161.

Haegeman, L. 2006a., Argument fronting in English, Romance CLLD and the left Periphery. In: Zanuttini, R., Campos, H. Herburger, E., Portner , P. (Eds.), Negation, Tense and Clausal Architecture: Cross-linguistic Investigations. Georgetown University Press, pp. $27-52$.

Haegeman, L. 2006b., Clitic climbing and the dual status of sembrare. Linguistic Inquiry 37, 484-501.

Haegeman, L. 2006c., Conditionals, factives and the left periphery. Lingua 116, 1651-1669.

Haegeman, L., 2007. Operator movement and topicalisation in adverbial clauses. Folia Linguistica 41, 279-325.

Haegeman, L., 2008. The syntax of adverbial clauses and the licensing of Main Clause Phenomena. Truncation or intervention? Paper presented at the 31st GLOW Conference, University of Newcastle 26-28 March 2008.

Haegeman, L., to appear. Main clause phenomena and the derivation of adverbial clauses. Proceedings of the 18th International Symposium on Theoretical and Applied Linguistics (ISTHAL). Aristotle University of Thessaloniki (4-6/05/2006).

Heinämäkki, O., 1978. Semantics of English Temporal Connectives. Ph. D. dissertation, Department of Linguistics, University of Helsinki. Reproduced by Indiana University Linguistics Club.

Hernanz, M.L., 2007a. From polarity to modality. Some (a)symmetries between bien and sí in Spanish. In: Eguren, L., Fernández Soriano, O. (Eds.), Coreference, Modality and Focus. John Benjamins, Amsterdam / Philadelphia. 133-169.

Hernanz, M.L., 2007b. Emphatic polarity and C in Spanish. In: Brugè, L. (Ed.), Studies in Spanish Syntax. Libreria Editrice Cafoscarina, Venezia, pp. 104-150.

Heycock, C., 2006. Embedded root phenomena. In: Van Riemsdijk H., Everaert, M. (Eds.), The Blackwell Companion to Syntax. Blackwell, Oxford, Vol. II: pp. 174-209.

Holmberg, A., 2005a. Is there a little pro? Evidence from Finnish. Linguistic Inquiry 37, 533564. 
Holmberg, A., 2005b. Stylistic fronting. In: Everaert, M., Van Riemsdijk, H. (Eds.), The Blackwell Companion to Syntax. Oxford: Blackwell: pp. 532-565.

Hooper, J. Thompson, S., 1973. On the applicability of Root transformations. Linguistic Inquiry 4, 465-97.

Hornstein, N., 1990 As Time goes by. Tense and Universal Grammar. MIT Press, Cambridge, MA.

Julien, M. 2008., Embedded V2 in Norwegian and Swedish. Working Papers in Scandinavian Syntax 80, 103-161.

Kayne, R., 1984. Connectedness and Binary Branching. Foris, Dordrecht.

Kayne, R., 1986. Connexité et inversion du sujet. In: Ronat, R., Couquaux, D. (Eds.), La Grammaire Modulaire. Editions de Minuit, Paris, pp. 127-147.

Kayne, R., 2000. Null subjects and clitic climbing. In: Parameters and Universals. Oxford University Press, Oxford \& New York, pp. 40-59.

Kayne, R., 2008. Antisymmetry and the Lexicon. Ms. NYU.

Kayne, R.,. Pollock, J.-Y., 2001. New thoughts on Stylistic Inversion. In: Hulk, A., Pollock, J.-Y. (Eds.), Subject Inversion in Romance and the Theory of Universal Grammar. Oxford University Press, Oxford and New York, pp. 107-162

Kempchinsky, P. 1987. The subjunctive disjoined reference effect. In :Neidle, C. and R.A. Nunez Cedeno (eds.), Studies in Romance Languages. Pp. 123-140.

Koster, J., 1978. Why subject sentences don’t exist. In: Keyser, S.J. (Ed.), Recent Transformational Studies in European Languages. MIT Press, Cambridge, MA, pp. 53-64.

Laenzlinger, C., Musolino, J., 1996. (Complex) Inversion and triggers. Geneva Generative Papers 3, 77-96.

Lahne, A., 2008. Local modelling of long distance agreement. Paper presented at the $31^{\text {st }}$ GLOW Conference, University of Newcastle 26-28 March 2008.

Lahousse, K., 2003a. The Distribution of Postverbal Nominal Subjects in French. A Syntactic, Semantic and Pragmatic Analysis. Ph.D. Dissertation, University of Leuven.

Lahousse, K., 2003b. La distribution de l'inversion nominale en français dans les principales non interrogatives et les subordonnées circonstancielles. Linguisticae Investigationes 26, 123-158.

Landau, I., 2008. Two routes to Control: Evidence from Case transmission in Russian. Paper presented at the $31^{\text {st }}$ GLOW Conference, University of Newcastle 26-28 March 2008. 
Larson, R., 1985. On the syntax of disjunction scope. Natural Language and Linguistic Theory 3, 217-264.

Larson, R., 1987. 'Missing prepositions' and the analysis of English free relative clauses. Linguistic Inquiry 18, 239-266.

Larson, R., 1990. Extraction and multiple selection in PP. The Linguistic Review 7, 169-182.

Larson, R. K., Sawada, M., 2004. Presupposition and root transforms in adjunct clauses. NELS 34.

Lasnik, H., Saito, M., 1992. Move $\alpha$. MIT Press, Cambridge.

Lipták, A., 2005. Relativization strategies in temporal adjunct clauses. LIVY Yearbook 5. John Benjamins, Philadelphia/Amsterdam, pp. 133-185.

Maki, H., Kaiser, L., Ochi, M., 1999. Embedded topicalization in English and Japanese. Lingua 109, 1-14.

McCloskey, J., 2006. Questions and Questioning in a Local English. In: Zanuttini, R., Campos, H., Herburger, E., Portner, P. (Eds.), Negation, Tense and Clausal Architecture: Cross-linguistic Investigations. Georgetown University Press, pp. 86126.

Meinunger, A., 2005. Remarks on the verb second phenomenon, the nature of volitional predicates, 'Konjunktive' and speculations on illocution. Ms. Zentrum fur Allgemeine Sprachwissenschaft. Berlin.

Melvold, J., 1991. Factivity and definiteness. In Cheng, L., Demirdache, H.(Eds.), More Papers on Wh-Movement, MIT Working Papers in Linguistics. No. 15. MIT: Cambridge, Mass. pp. 97-117

Miller, P., 2001. Discourse constraints on (non) extraposition from subject In English. Linguistics 39, 683-701.

Miyagawa, S. 2005. Unifying agreement and agreement-less languages. Proceedings of WAFL2, MIT working papers in linguistics.

Munaro, N., 2005. Computational puzzles of conditional clause preposing. In: di Sciullo, A.M. (Ed.), UG and External Systems. Language, Brain and Computation. John Benjamins, Amsterdam/Philadelphia, pp. 73-94.

Nilsen, Ø., 2004. Domains for adverbs. In: Alexiadou, A. (Ed.), Adverbs across Frameworks, Lingua 114, 809-847.

Palmer, F.R., 1990. Modality and English Modals. Longman, London.

Papadopoulou, D., Tsimpli, I., in collaboration with Mylonaki, A.. This volume. Temporal modification in Greek adverbial clauses. The role of aspect and negation. 
Penner, Z., Bader, T., 1995. Issues in the syntax of subordination/ a comparative study of the complementizer system in Germanic, Romance, and Semitic languages with special reference to Swiss German. In: Penner, Z. (Ed.), Topics in Swiss German Synta., Peter Lang, Bern, pp. 73-290.

Quirk, R., Greenbaum, S., Leech, G., Svartvik, J., 1985. A Comprehensive Grammar of the English Language. Longman, London.

Riemsdijk, H. van, Everaert, M., (Eds.), 2006. The Blackwell Companion to Syntax. Blackwell, Oxford \& Boston.

Rizzi, L., 1982. Violations of the $w h$-island constraint and the subjacency condition. In: Rizzi, L (Ed.), Issues in Italian Syntax. Foris: Dordrecht, pp. 117-84.

Rizzi, L., 1990. Relativized Minimality. MIT Press, Cambridge, MA.

Rizzi, L., 1997. The fine structure of the left periphery. In: Haegeman, L. (Ed.), Elements of Grammar. Kluwer, Dordrecht, pp. 281-337.

Rizzi, L., 2000. Reconstruction, Weak Island sensitivity and agreement. Ms. University of Siena.

Rizzi, L., 2001. On the position Int(errogative) in the Left Periphery of the clause. In: Cinque, G. , Salvi, G. (Eds.), Current Studies in Italian Syntax. Essays offered to Lorenzo Renzi. North-Holland, Amsterdam, pp. 286-296.

Rizzi, L., 2004. Locality and left periphery. In Belletti, A., (Ed.), Structures and Beyond. The Cartography of Syntactic Structures, vol. 3. Oxford University Press, Oxford, pp. 223251.

Roberts, I., Roussou, A., 2002. The Extended Projection Principle as a condition on the Tense dependency. In: Svenonius, P. (Ed.), Subjects, Expletives and the IPP. Oxford University Press, New York and Oxford, pp. 125-155.

Roberts, I., Roussou, A., 2003. Syntactic Change. Cambridge University Press, Cambridge.

Rögnvaldsson, E., Thraínsson, H., 1990. On Icelandic word order once more. Working Papers in Scandinavian Syntax. 58, 55-86.

Rutherford, W., 1970. Some observations concerning subordinate clauses in English. Language 46, 97-115.

Samek-Ludovici, V., 2007. Asymmetries between pre- and post-focus left-peripheral topics in Italian. LAGB, King's college London 2007.

Sigurđsson, H., 1989. Verbal Syntax and Case in Icelandic. PH.D. Dissertation : Lund University.

Sobin, N., 2003. Negative inversion as non-movement. Syntax 6, 183-222. 
Sportiche, D., 1981. Bounding nodes in French. The Linguistic Review 1, 219-46.

Starke, M. 2001. Move dissolves into Merge. Ph.D. Diss. University of Geneva.

Stowell, T., 2004. Tense and modals. In: Guéron, J., Lecarme, J. (Eds.), The Syntax of Time. MIT press, Cambridge, MA, pp. 621-636.

Stump, G., 1985. The Semantic Variability of Absolute constructions. Kluwer, Dordrecht.

Stephens, N., 2006. Norwegian when-clauses. In: Butt, M., King, T.H. (Eds.), Proceedings of the LFG06 Conference. Universität Konstanz, pp. 476-484.

Tenny, C., 2000. Core events and adverbial modification. In: Tenny, C., Pustejovsky, J. (Eds.), Events as Grammatical Objects. CSLI Publications, Stanford, pp. 285-334.

Tomaszewicz, B., to appear. Subjunctive Mood in Polish. Proceedings of the FDSL7-conference. Frankfurt am Main: Peter Lang.

Verstraete, J.-C., 2002. Interpersonal Grammar and Clause Combining in English. Ph.D. dissertation: University of Leuven.

Whitman, J., 1989. Topic, modality, and IP structure. In: Kuno, S. et al (Eds.), Proceedings of the Third Harvard workshop on Korean linguistics. Seoul: Hanshin.

Zagona, K., 2007. On the syntactic features of epistemic and root modals. In: Eguren, L. and Fernández Soriano, O. (Eds.), Coreference, Modality and Focus. John Benjamins, Amsterdam/Philadelphia, pp. 221-236.

Zanuttini, R., Portner, P., 2003. Exclamative clauses: at the syntax-semantics interface. Language $79,39-81$.

Zribi-Hertz, A., Diagne, L., 2003. Déficience flexionnelle et temps topical en wolof. In : Sauzet, P., Zribi-Hertz, A. (Eds.), Typologie des Langues d'Afrique et Universaux de la Grammaire, vol. 2: Benue-Kwa et Wolof. L’Harmattan, Paris, pp. 205-231.

Zubizaretta, M.-L., 2001. Preverbal subjects in Romance interrogatives. In: Hulk, A., Pollock, J.Y (Eds.), Subject Inversion in Romance and the Theory of Universal Grammar. Oxford Studies in Comparative Syntax, Oxford University Press, Oxford and New York.

\footnotetext{
Versions of this paper were presented at the 18th International Symposium on Theoretical and Applied Linguistics. Aristotle University of Thessaloniki. (4-6/5/2007), at the Syntax Lab at the University of Cambridge (18.5.7), at the LAGB (King's College, London), at the International Symposium on Linguistics: Syntactic Structure and Functional categories, Kanda University of International Studies: Graduate School of Language Sciences, Tokyo (21.10.07), at the FORELL research group (University
} 
of Poitiers), at the Autonoma University (Barcelona), at the $31^{\text {st }}$ GLOW Conference, Newcastle 2008. I thank the various audiences for their comments.

Special thanks are due to the many colleagues who have contributed to this paper by their comments and suggestions: Dora Alexopoulou, Rhajesh Bhatt, Teresa Biberauer, Anna Cardinaletti, Guglielmo Cinque, Yoshio Endo, Michel DeGraff, Hamida Demirdache, Ilse Depraetere, Kleanthes Grohmann, Jacqueline Guéron, Noguko Hasegawa, Iliyana Krapova, Karen Lahousse, Terje Lohndal, Shigeru Miyagawa, Christopher Pinon, Luigi Rizzi, Anna Roussou, Ian Roberts, Joachim Sabel, Heloise Salles, Halldor Sigurđsson, Michal Starke, Ianthi Tsimpli and Jeroen Van Craenenbroeck.

I also thank two reviewers for thorough and challenging remarks. Obviously none of them can be held responsible for the use I made of their comments. The same observation has been made, for instance, for Finnish (Holmberg 2005a: 548: n11: (ii)), Japanese (Maki et al 1999), and Korean (Whitman 1989) (see also Haegeman 2006b). The analysis provided here also accounts for the ungrammaticality of VP preposing, preposing around be and locative inversion in English adverbial clauses. See Haegeman (2008, to appear) . See also Emonds (2004). I do not claim that all MCP are amenable to a syntactic analysis, nor do I imply that the domains that are incompatible with MCP are a homogeneous class. Further empirical research is required here. For the incompatibility of high modals with conditional clauses cf. Nilsen (2004) and Ernst (2007, 2008). For restrictions on modal particles in German adverbial clauses see Coniglio (2007). Heinämäkki (1978: 38, note 1) signals some problematic examples. I refer to her work for discussion.

5 As observed by a reviewer the examples in (4) and elsewhere improve with comma intonation: thus (4a) is much improved in (i) with comma intonation for frankly:

(i) When, frankly, he was unable to cope...

The same effect is observed for the examples in (5) below.

I agree with these judgments. At this point I have no account for such improvements to offer here. But it seems to me that the comma intonation has the effect of relegating the adverbials to the status of parentheticals, and it is well known that parentheticals may appear in rather unexpected positions. A reviewer remarks that 'semantically equivalent phrasal adverbials work better in these cases' and gives the following examples:

(i). If, by some misfortune, we don't find him...

(ii) Since, to her good fortune/by sheer luck, she discovered this baker's shop...

I agree with the judgments but two remarks are in order. First the comma intonation seems in general to have the effect of improving the sentences, for reasons that are unclear to me (see preceding note). Second, I am not convinced that it is true that the PPs in (i) and (ii) are semantically equivalent to the adverbs. In particular, the intended reading for the evaluatives unfortunately, fortunately and luckily which gives rise to ungrammaticality in the text examples (5) is that in which the speaker pronounces an evaluation and the evaluation is from his own point of view ('(un)fortunately for me', 'luckily for us'). In (ii), though, to her good fortune is clearly subject related and the same can be said for by sheer luck. The person who is lucky is 'she', the subject.

I also refer to Ernst (2007: 1028) for complications with respect to evaluatives. 
For Dutch schijnen ('seem') and lijken ('appear') see Haegeman (2005, 2006b).

A reviewer points out that it would be interesting to examine whether evidential inflection, as found for instance in Turkish, is compatible with adverbial clauses. I hope to pursue this in the future.

The same reviewer points out that the distribution of allegedly may be more complex. This needs further study. See also notes 5 and 6.

Observe that it is not always easy to draw conclusions from the surface distribution of what would appear to be evidential markers. In Italian, for instance, sembrare ('seem') might appear to have 'evidential' meaning, but it clearly has two uses, one lexical and another functional. It is only the latter use that has the restricted distribution. It is conceivable that adjuncts which would at first sight appear to be 'high functional adverbs' in fact also have a lexical use and that this allows them to appear in central adverbial clauses. One would expect subtle interpretive differences to appear. The PP adjuncts discussed in note 6 might be a case in point.

See Rizzi's own paper (1997; note 6).

Force was located low in the CP. This fell out from the truncation analysis: if ForceP was not projected then neither were FocP or TopP. Different implementations are conceivable to state the dependency of topicalisation on Force. For instance, the head Topic might have an [uForce] feature which has to be checked by a corresponding [Force] feature on the head Force.

See, though, McCloskey (2006) for restrictions.

The relevant adjuncts are discussed in Browning (1996), they also alleviate that-trace effects. See Bowning (1996), Rizzi (1997) and Haegeman (2003b).

For more examples see Haegeman (2007).

A reviewer for this paper points out that the situation in Modern Greek is more complicated in that CLLD is generally degraded in adverbial clauses of the type shown in (1). However, there is variation: it is acceptable in conditional clauses, while less good in temporal clauses introduced by eno ('while'). Papadopoulou et al (this volume) provide the following data (their (19) and (20)):

(i) An tis telikes eksetasis dhen tis perasis, dhen tha paris ptixio.

if the final exams not them pass not will get degree

'If you don't pass the final exams, you won't get the degree.'

*Kathos to vivlio to dhiavaze, e vlepe tileorasi.

Kathos the book read-IMPERF-3SG watch-IMPERF-3SG TV

'While he was reading the book, he was watching TV.'

Obviously the data in (ii) are puzzling. However, it is also pointed out that CLLD is possible if the topicalized constituent precedes the temporal conjunction: (Papadopoulou et al this volume: their (24a)) (iii) To vivlio kathos to dhiavaze, evlepe tileorasi.

the book kathos it read-IMPERF-3SG watch-IMPERF-3SG TV

'While he was reading the book, he was watching TV.'

I will not pursue the Greek data here. For an account I refer to Papadopoulou et al, this volume. complementation and might therefore strike some readers as less than fully normal' (2001: 297, note 14). 
I have added (coindexed) traces $(\mathrm{t})$ in the examples merely to facilitate parsing.

High/low construal is also available with before, until, (temporal) since (Larson 1990: 170). Low construal is unavailable with while:

(i) I didn't see Mary in New York while she said she was there. (Geis 1970, Stump 1985, Larson 1990: 174, (11a))

See also Citko (to appear), Liptàk (2005), Stephens (2006).

Given that argument fronting is excluded in temporal while-clauses I assume that they are derived by movement.

Gaelic adverbial clauses with when are underlyingly relatives (David Adger p.c):

(i) Nuair a dh'fhàg thu an-raoir, an do chuir thu dheth na solais.

when-REL left you last night, Q PS put you off the lights

'When you left last night, did you switch off the lights?'

As also observed by a reviewer for this volume.

Gaelic if-clauses are also relative clauses (David Adger, p.c). This is shown by the inflection on the verb:

(i) Ma bhios mi ann, cha bhi e toilichte.

if be-REL.FUT I there, NEG be-FUT he happy

'If I'm there, he won't be happy.'

CLLD is sensitive to strong islands. For instance, it is subject to the CNPC, as shown in (i) from Alexopoulou et al (2004: 343: (40)

(i) * A Carlo, ti parlerò solo delle persone che gli piacciono.

to Carlo, you talk-FUT-1SG only of-the people that him please-3PL

Boeckx and Jeong (2004: 18): 'we regard [Topicalized and Focused elements] both as quantificational elements (forming operator variable chains), possessing a $[+Q]$, feature'. This implies a similarity between topics and D-linked wh-phrases (cf. Grohmann 2005, Boeckx and Grohmann 2004)

But see Benincà and Polletto (2004: 57), Samek Ludovici (2007) on Foc>Top.

I explore additional empirical consequences in Haegeman (2007, 2008, to appear).

Abels and Muriungi (2008: 693-4) show that focus marking in Kîtharaka is allowed in central adverbial clauses and banned in peripheral adverbial clauses. While adopting the truncation account for their discussion they point out (2008: 604) that the intervention account can also handle the data.

'There is a secondary conjunctive interpretation that all these connectives (as, while, when) shade into. They get an interpretation similar to and in these contexts. And is not a temporal connective, and these conjunctive interpretations do not tell against the theory [of temporal subordination and complex tense structures].' (Hornstein 1990: 206: note 19).

SI can also be triggered by the subjunctive:

(i) Je voudrais que soient invités tous les étudiants de première année.

I want-COND-1SG that be-SUBJ-3PL invited-PART-PL all the students of the first year

I have nothing to say about the trigger in such contexts. 
28 Conditional clauses do not allow SI, nor do yes no questions. If the relevant operator which derives conditionals starts out from the specifier of FinP, this is too high a position to license stylistic inversion. For reasons of space I cannot go into this here.

On factive verbs and semifactives see also Hooper and Thompson (1973: $480 \mathrm{ff}$.). Maki et al show that there is variation among speakers. I have nothing to say about this here. See also Green (1996). Lasnik and Saito (1992: 77) accept (i):

(i) That this solution I proposed last year is widely known. (1992: 77, their (43)) For subject clauses, see Koster (1978), Davies and Dubinsky (1999) and Miller (2001). 